\title{
林齢の異なる放置ヒノキ人工林における風致間伐の 伐採木選木に関する考察
}

\author{
Consideration about Selecting Felled Trees to Practice "Scenic Beauty Thinning" at Different Forest \\ Age of Neglected Chamaecyparis Obtsusa Forest Stands
}

\author{
清水 裕子* 川崎 圭造** 伊藤 精晤** 林 勝也*** \\ Yuko SHIMIZU Keizou KAWASAKI Seigo ITOH Masaya HAYASHI
}

\begin{abstract}
We said, in the previous report, that scenic beauty thinning is more effective than ordinary thinning to transit Hinoki cypress from its mass artificial forest to the mixed forest. To do scenic beauty thinning, we have to recognize what kind of type the tree form belongs to but actually it is hard to recognize it properly and apply it because there was a big difference between individual judgments. Our purpose, in this report, is to investigate the individual species competition and tree form of untouched cypress artificial forest. And also we aimed to quantitatively consider the standard to choose trees for scenic beauty thinning in cypress artificial forest. We investigated the cypress artificial forest (some types of age) untouched for at least 30 years. As a result, there were not any factors (deciding tree forms) having a competitive influence on the individual trees and neighboring trees. Obviously there are not still competitive relationships between comparatively high-density massive trees and neighboring trees. It is hard to choose trees for scenic beauty thinning in cypress artificial forest. Therefore we found that the conventional method would have to be reconsidered.
\end{abstract}

Keywords: scenic beauty thinning, tree class, specific competition, Chamaecyparis obtsusa forest stands キーワード : 風致間伐, 樹形, 樹型級, 種内競争, ヒノキ人工林

\section{1. 研究の背景}

近年, 林業の低迷から森林が放置されているのに対して, 森林 の多目的利用に対する関心が高まっている。中でも森林の保健・ 休養利用であるキャンプやエコッーリズムのようなアウトドア・ レクリエーション利用や, 自然観察, 林間学校のような環境教育 など, 現代の多様な価值観に伴った多様な需要が増加している。 この多様な需要に対応できる, 魅力的で風致を感じる豊かな自然 環境が成立した森林を創出する事は急務であるといえる》。また この事は, 都市の目が地方農山村に向かい, 地方農山村の森林へ の価值が上昇してきていることを意味する。地方農山村の方でも, 地域振興対策の切り札としてこのような利用を視野に入れた森林 整備に対する関心は高い占)。

一方，地方農山村の森林の現状はというと，集落に近接した条 件の良い立地にも拡大造林期に植林されたスギ・ヒノキ人工林が, 多くを占めている。しかし, これらの林地は林業の衰退や過疎化 による林業労㗢者の激減が原因で手入れ不足のまま, 伐期を過ぎ てもな敃置されている。人工林の放置は, 過密になった人工林 では林木の生長の減退, これに伴う根系の発達不良による冠雪害 や強風での倒木被害が増加, 被圧木や枯死木の放置による病害虫 の発生, さらに, 林冠のうっ閉による林床植生の衰退やこれに伴 う林床の裸地化が起因する表層土壤の流亡など, その問題は枚挙 に暇がない。これらの林地の荒廃によって, その健全性や風致は 著しく損なわれているといえる。

こうした森林もレクリエーション利用の立地条件の良さなどか ら生活環境保全林や森林公園などにかなりの面積が編入されてい る。これらの森林も依然放置されている現状がある。その背景之 して, 前述した林業的な問題や過疎, 林地の経済性などの諸問題 ああるが, 森林整備の技術の欠如, 整備した後の風致的評価がな されていない事が挙げられる。現在, 放置人工林のレクリエーショ
ン利用を目的とした森林育成技術，すなわち森林風致技術の展開 は急務であるといえる(15)。

\section{2. 研究の目的}

手入れ不足の人工造林地に対する森林レクリエーションの目的 と森林育成の技術に二つの目標が設定できる。

1) 多面的な森林機能を維持させながら自然的で多様であり, か つ利用者が風致を感じる, 保健レクリエーション目的を第一 義とした森林構造を創出する。

2) さらに高齢林として育成することにより，1）を達成しつつ木 材を収穫する目的む二義的に考慮に入れる。

である。特に対象樹種がスギ・ヒノキである場合, 経済性が無視 できない。放置され，過密となった人工造林地では強間伐（本数 間伐率 50\%以上）が必要となるが，この間伐方法において前生 樹の育成抢よび天然更新を期待した針広混交の択伐林型を目標之 し，林木の育成を持続させることで上記の二つの目標を実現でき るとされている。

前報で筆者らは，ヒノキの放置人工林を対象として上記の目標 設定の施業上の条件を満たす方策として「風致間伐」を挙げ3), その間伐効果について強度の間伐率（本数間伐率 $60 \%$ ）での通 常間伐（下層間伐）之同等の間伐率を施した「風致間伐」との 7 年後の間伐効果を比較して考察した8)。その結果, 高木層の成長 については両者の間に差異は生じなかったが，林床の前生樹には 一定の成果があり，「風致間伐」を施した林分では間伐後の林木 の平面配置により生じた小ギャップの㗢きで，林床での高木類の 幼稚樹の樹高の不斉化には通常間伐と比較して効果的であった。 しかし，この間伐方法については同時に課題あ生じた。それは伐 採木選木の際に寺崎式樹型級区分に類似した樹形区分を行うが, この樹形区分は一斉林である人工林では微妙な差であり，その差

\footnotetext{
**岐皁大学連合大学院連合農学研究科 ${ }^{* *}$ 信州大学 ${ }^{* * *}$ 信州大学大学院
} 
の区分は経験的で主観的なものである点で，規則的な方法として の確立は困難であったことである。

寺崎式樹型級区分は, 主に樹冠形によって区分されるが，うっ 閉が始まった林分では, 隣接木の位置関係（競争関係）によって 樹冠形が規定されるとしている ${ }^{10)}$ 。そこで本研究は,「風致間伐」 の再現性や実行性を視野に入れ，上ノキ放置人工林において個体 レベルでの隣接木との競争関係と樹型（樹冠形）の関係を明らか にし, 風致間伐選木基準 ${ }^{17}$ を定量化した後, その間伐方法につい て定量的に考察することを目的とした。

\section{3. 調査地概要および調査対象地}

調查地は長野県南部に位置する上伊那郡飯島町の町有林之共有 林の七ノキ人工林で， 82 年生の 27 林班（八小班）と 53 年生の 14 林班（口小班), 31 年生の 20 林班（八小班）である。林齢は 31 年生の林分に関しては共有林の代表からの聞き取りにより, 他の二つの林分に関しては森林簿によって調べた。以降は便宜的 に 80 年生, 50 年生, 30 年生とする。 50 年生と 80 年生に関して は町の資料により, 80 年生に関しては以前ナスビ伐りを行った ということ, 昭和 48 年以降, 施業来歴は無く, 30 年生に関して は共有林の代表者からの聞き取りによって植栽数年後に広葉樹の 除伐後は無間伐のまま放置していた事がわかった。立木本数は 30 年生で 1950 本/ha, 50 年生は 1150 本/ha, 80 年生は 700 本/ ha で，施業林として考えればいずれも高密だといわれる林分で ある。森林簿によると, 地位指数はいずれあ 2 で, 80 年生が斜 面方位は北東で傾斜約 $26^{\circ}, 50$ 年生が斜面方位は北で傾斜約 $9^{\circ}$, 30 年生が斜面方位が東で傾斜約 $8^{\circ}$ であった。林内はいずれも暗 く, 林床植生もいずれも乏しく, 特に 30 年生のプロットでは, 低木層さえまばらな状況で, わずかな草本層と上層木のみであっ た。

\section{4. 調查方法}

調查は 2004 年 8 月 17 日から 9 月 13 日の間に行った。レーザー 測距計（LaserTechnology 社製 Impulse）を用い，各林分に $20 \mathrm{~m}$ 四方の調查プロットを設置し, それぞれについて下記の調 查項目を打こなった。

(i ) 毎木調査

胸高直径 $10 \mathrm{~cm}$ 以上の林木について, 樹木位置, 樹高, $\mathrm{DBH}$, 枝下高, 樹冠幅, 樹冠面積を測定した。測定は正確さを期す為に 樹木位置, 樹高, 枝下高, に関しては前出のレーザー測距計にて 測定し, DBH は輪尺にて測定し, 樹冠幅む同様に巻尺にて 8 方 位を測定した。樹冠面積は樹冠幅, 樹木位置デー夕を用い, $\mathrm{CAD}$ ソフト(A\&A 社 Vector Works) にてソフト内部言語 （Vector Script）によってプログラミングし，樹冠投影図を作成 した。この際, 樹冠は 8 方位の点をべジェ曲線で結ぶ事によって 描画し,パソコン画面上でそれらの面積を出した。

(ii) 階層構造調査および植生調査

階層構造調查はプロットの各樹高階層組毎に目視判断にて被度 を測定した後, 階層構造組毎に樹種を同定して植生調査を行った。

(iii）樹冠開空度調査

各林内に打いて 1 プロットに 3 箇所ずつ(図 - 1 参照), $\mathrm{H}=1.3 \mathrm{~m}$ の位置で水平に固定された魚眼レンズ (FisheyeNikkor) を装着したカメラにより全天空写真の撮影を行った後, パソコン画面にて写真加工ソフト（Adobe 社 Photoshop）によ り白黒二階調化し, 開空部分の画素数の百分率から 3 䈏所の平均 值を開空度として算出した。

(iv) 分散構造

分散構造は毎木調査より前出の CAD ソフトにて樹木位置図を 作成し, パソコン画面上でプロットの 1 辺を 8 分割し, 分布様式
をMorishita のI $\delta$ 指数で算出し, 調べた ${ }^{6),}$, ${ }^{9}$ 。

( $\mathrm{v}$ ) 競争指数

立木間の競争状態を Hegyi の競争指数を用いて表した ${ }^{12)}$ 。競 争指数については林内の立木間の競合を考慮した研究は多くなさ れているが，その中でも個体サイズに距離情報を組み込んだ競争 指数の有効性が報告されていることから ${ }^{14)}$ ，本報では競争指数に， 隣接木の DBH と個体間距離を計算式に包含した Hegyi の競争 指数を用いた ${ }^{222}$ 。

\section{5. 結果}

表一 1 に各プロットの概況を示した。各プロットはその林齢之 1 ha 当りの成立本数から, 長野県の木曾地方の七ノキ施業指針 ${ }^{13}$ ) に照らし合わせた場合，いずれのプロットにおいても高密と判断

$$
\text { 表一 } 1 \text { 各プロットの概況 }
$$

\begin{tabular}{ccccc}
\hline 林齢 & 成立本数 $($ 本 $/ \mathrm{ha})$ & $\mathrm{DBH}(\mathrm{cm})$ & 樹高 $(\mathrm{m})$ & 枝下高 $(\mathrm{m})$ \\
\hline \hline 30 & 1950 本 $/ \mathrm{ha}$ & $19.6 \pm 4.89$ & $15.61 \pm 1.4$ & $8.61 \pm 1.19$ \\
50 & 1180 本 $/ \mathrm{ha}$ & $24.42 \pm 8.1$ & $17.3 \pm 1.79$ & $8.35 \pm 1.3$ \\
80 & 700 本/ ha & $29.82 \pm 6.9$ & $21.38 \pm 1.3$ & $8.59 \pm 1.56$ \\
\hline \multicolumn{5}{c}{} \\
\hline 林齢 & 樹冠長率 $(\%)$ & 樹冠面積 $\left(\mathrm{m}^{2}\right)$ & 相対幹距比 & 形状比 \\
\hline \hline 30 & $44.41 \pm 8.75$ & $5.43 \pm 3.09$ & 15.31 & 0.80 \\
50 & $51.25 \pm 9.15$ & $11.57 \pm 6.42$ & 17.05 & 0.71 \\
80 & $59.76 \pm 7.48$ & $20.63 \pm 8.43$ & 19.94 & 0.72 \\
\hline
\end{tabular}

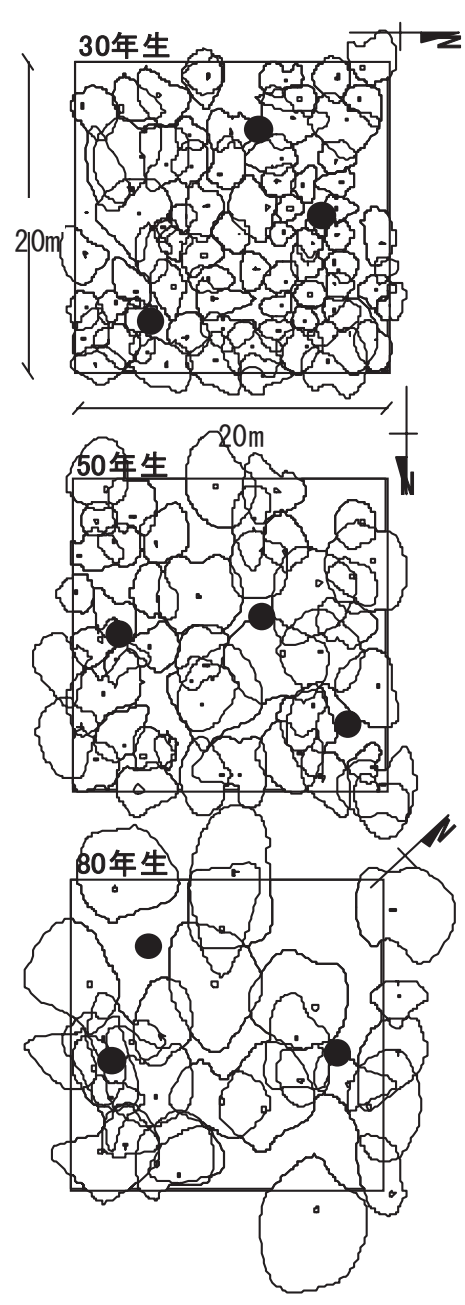

図中のは樹冠開空度の撮影地点を表す。 図一1 各プロットの樹冠投影図 
される密度であることが明らかになった。また，相対幹距比 ${ }^{1121)}$ に関しても，30 年生で超過密，50 年生で過密，80 年生で高密之 判断される值をとり, 成立本数, 相対幹距比からもすべてのプロッ トにおいて施業林としては高密な状態であることが示された。し かし一方，樹冠長率 ${ }^{18)}$ は約 45\% 60\%でそれほど值は小さくな く, 形状比むいずれも 0.7 から 0.8 であった5)。

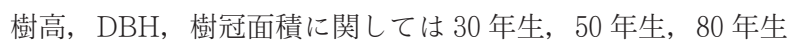
の順で值は大きくなった。その值のばらつきは DBH, 樹冠面積 で 30 年生，50 年生， 80 年生の順に大きくなったが，樹高に関し ては 80 年生では, 樹高のばらつきは他の二つのプロットよりも 小さい值が得られた。また，このプロットの樹高は表より 21.83 $\pm 1.3 \mathrm{~m}$ であったが，長野県の 80 年生の七ノキ樹高曲線 ${ }^{13)}$ による とこのプロットの地位 2 では樹高の上限が $23 \mathrm{~m}$ であり, このプ ロットはこの上限值に近い值に達していることが示された。

図ー 1 に各プロットの樹幹投影図を示した。図より，3つのプ ロットでそれぞれの立木配置に相違があることが明らかになった。 特に 80 年生では樹冠面積に大小のばらつきがあり, かつ林木が 小群状になって配置していた。

図ー 2 は各プロットの $\mathrm{DBH} 10 \mathrm{~cm}$ 以上の林木の平面空間分布 をMorishita のI $\delta$ を用いて, 調べたものである。30 年生では ランダム分布, 50 年生では一様分布に近いランダム分布を呈し た。一方， 80 年生に関しては，コドラートサイズ $1 / 8 \sim 1 / 2$ で集 中分布を呈し，I $\delta(\mathrm{s}) / \mathrm{I} \delta(2 \mathrm{~s})$ にっって集中斑の大きさはプロッ 卜面積の $1 / 8 \sim 1 / 2$ であることが明らかになった。

図ー 3 に DBH と樹高の関係を表した。80 年生は樹高が $21 \sim 22 \mathrm{~m}$ 付近に集中し, DBH と樹高の相関が低かった（ $\mathrm{r}^{2}$

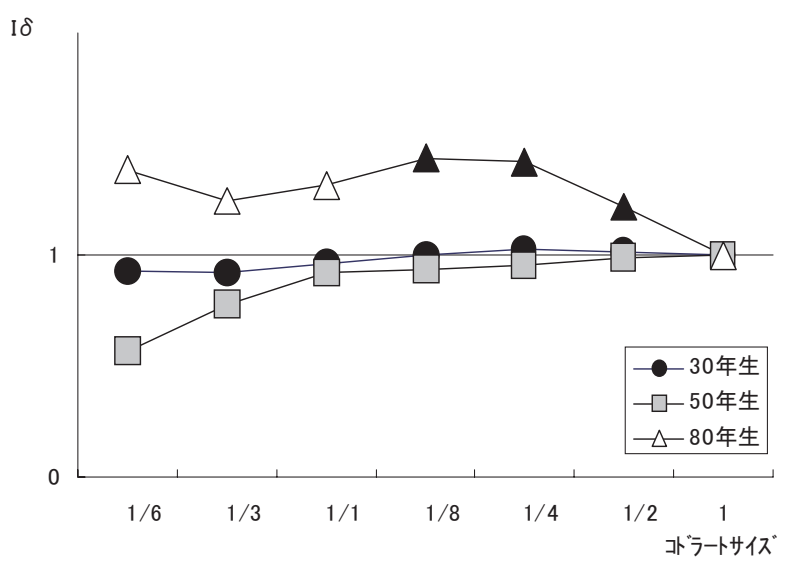

ムは F 検定により 1 から有意に差があるもの。

図－２＼cjkstart各プロットの分散構造図

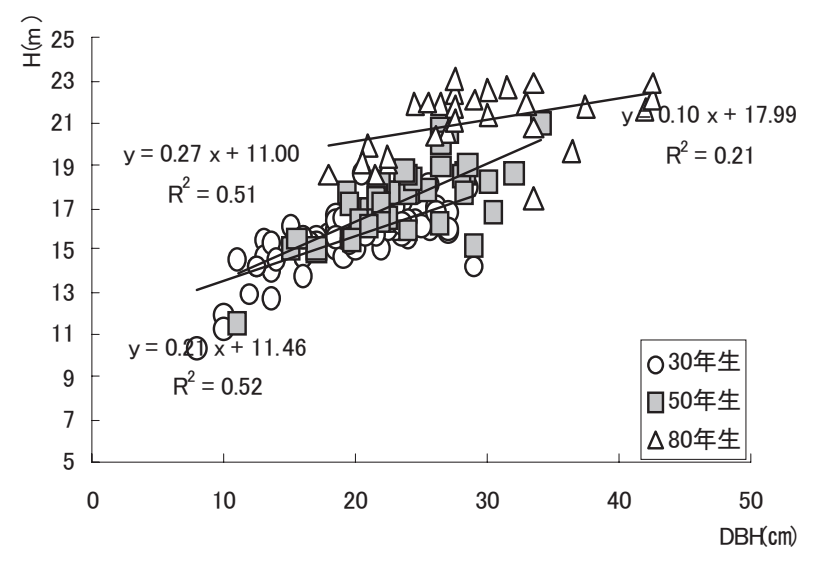

図ー３＼cjkstart各プロットの胸高直径と樹高の関係
$=0.21)$ のに対し, 30 年生, 50 年生では $\mathrm{DBH}$ と樹高の相関が $\mathrm{r}^{2}=0.53, \quad \mathrm{r}^{2}=0.51$ であり, 80 年生と比較して高かった。

図一 4 は相対幹距比々樹冠開空度の関係を示した。相対幹距比 とは林地の相対的な込み合いを示す指標で, 成立本数と樹高から 導かれ，值が小さいほど込み合っているとされる ${ }^{21}$ 。相対幹距比 の値が超高密に該当する 30 年生では樹冠開空度は低く, $10.75 \pm$ 0.38 であり, 他の二つのプロットと比較し，かなり低かった。 一方， 50 年生， 80 年生に扔いても，それぞれ $19.03 \pm 0.38,18.97$ 土1.36 と一般的な值よりも低かった。また， 80 年生では他の二 つのプロットよりも樹冠開空度の值のばらつきが大きかった。

図一 5 に森林階層構造図を表した。30 年生では高木層は 12 19m でヒノキがほとんどを占め, わずかにクリとウワミズ ザクラが数本存在し, 被度は $95 \%$, 亜高木層では 9 $11 \mathrm{~m}$ でヒ ノキ，クリ，ウワミズザクラが見られ，被度 $15 \%$ であった。低 木層 $1 \sim 3 \mathrm{~m}$ ，草本層 $50 \mathrm{~cm} \sim 1 \mathrm{~m}$ ，地衣類 $0 \sim 50 \mathrm{~cm}$ で，低木層 ではヤマッッジ, マルバアオダモ, 草本層ではヤマッッジの他に, マルバアオダモの稚樹, ツルマサキがみられ，地衣類はわずかに シダ類が見られたが，すべてにおいて被度は $5 \%$ 程度であった。

50 年生では高木層は $12 \mathrm{~m} \sim 21 \mathrm{~m}$ でヒノキに数本のサワラが存 在し, 被度は $90 \%$, 覀高木層 $3 \mathrm{~m} \sim 5 \mathrm{~m}$ でヒノキのほかにクリ, ウワミズザクラが見られ被度 $20 \%$, 低木層は $1 \mathrm{~m} \sim 3 \mathrm{~m}$ でマル バアオダモ, ヤマッッジがほとんどで被度 $70 \%$, 草本層は $50 \mathrm{~cm}$ 〜 $1 \mathrm{~m}$ でヤマゥルシが優占し, 他にマルバアオダモ, ッルマサ キが見られ，被度は $50 \%$, 地衣類 0 50cm でシダ類のほかにコ ケ類などで被度 70\%を占めていた。また 80 年生では $16 \mathrm{~m} \sim 24 \mathrm{~m}$ で高木層はすべてヒノキで被度 $85 \%$, 亜高木層は $5 \mathrm{~m} \sim 6 \mathrm{~m}$ で リョウブ, マルバアオダモ，イチイなどが被度 $10 \%$ を占めた。 低木層は $1 \mathrm{~m} \sim 5 \mathrm{~m}$ で被度 $50 \%$, 草本層は $50 \mathrm{~cm} \sim 1 \mathrm{~m}$ で被度 $50 \%$ であた。低木層と草本層の構成種は類似し，ホッッジ，バ イカッッジ，などのッッジ類が多く，他にコミネカエデ，ヒトッ バカエデ，コアジサイ，ノリウッギなどで構成されていた。地衣 類は 0 50cm でシダ類, コケ類などが見られ，被度は $35 \%$ であっ た。図からあ示されるように, すべてのプロットで程度の差はあ るが, 高木層が圧倒的な被度を有し, 下層の種構成には高木類が 少なく，貧弱な下層植生といえた。

図一 6 は算出した Hegyi の競争指数と DBH, 樹冠形を規定す る樹冠長, 樹冠面積との関係図を示した。樹冠幅と樹冠面積は当 然ながら高い相関を呈したので（ $r^{2}=0.96 ）$ ここでは樹冠面積 のみを取り上げた。図より 50 年生と 80 年生では競争関係は樹形

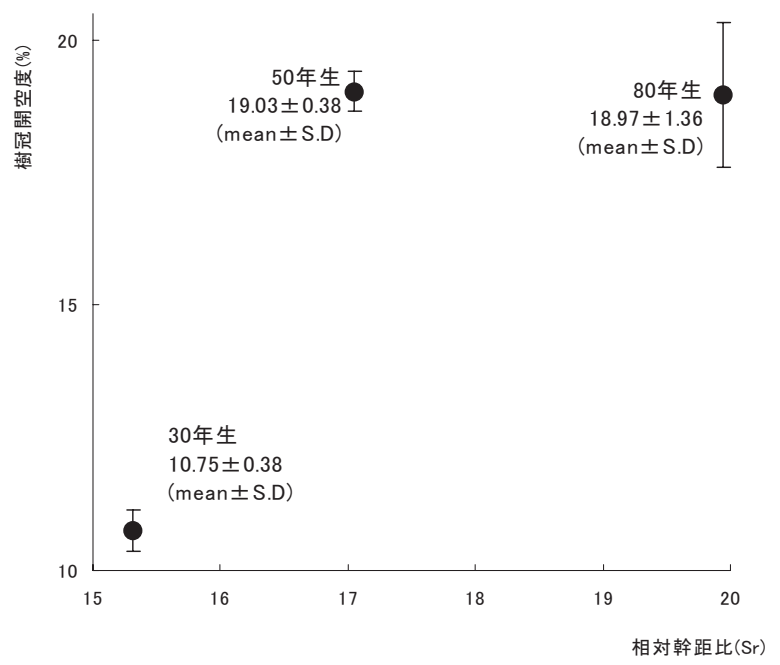

図－4＼cjkstart各プロットの相対幹距比と樹冠開空度の関係 

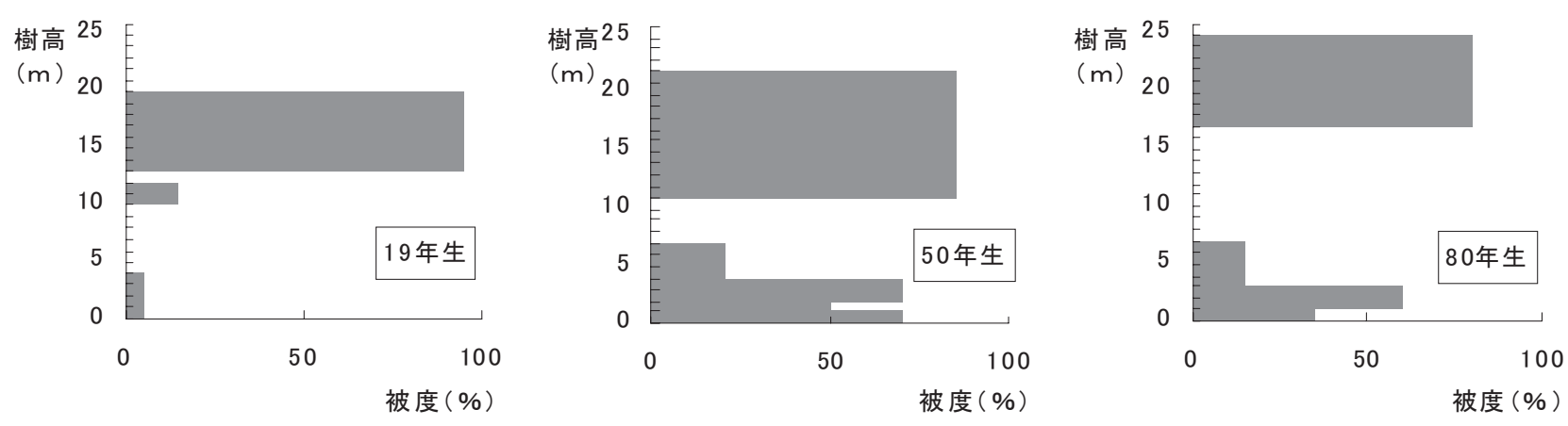

\section{図－５＼cjkstart各プロットの森林階層構造図}
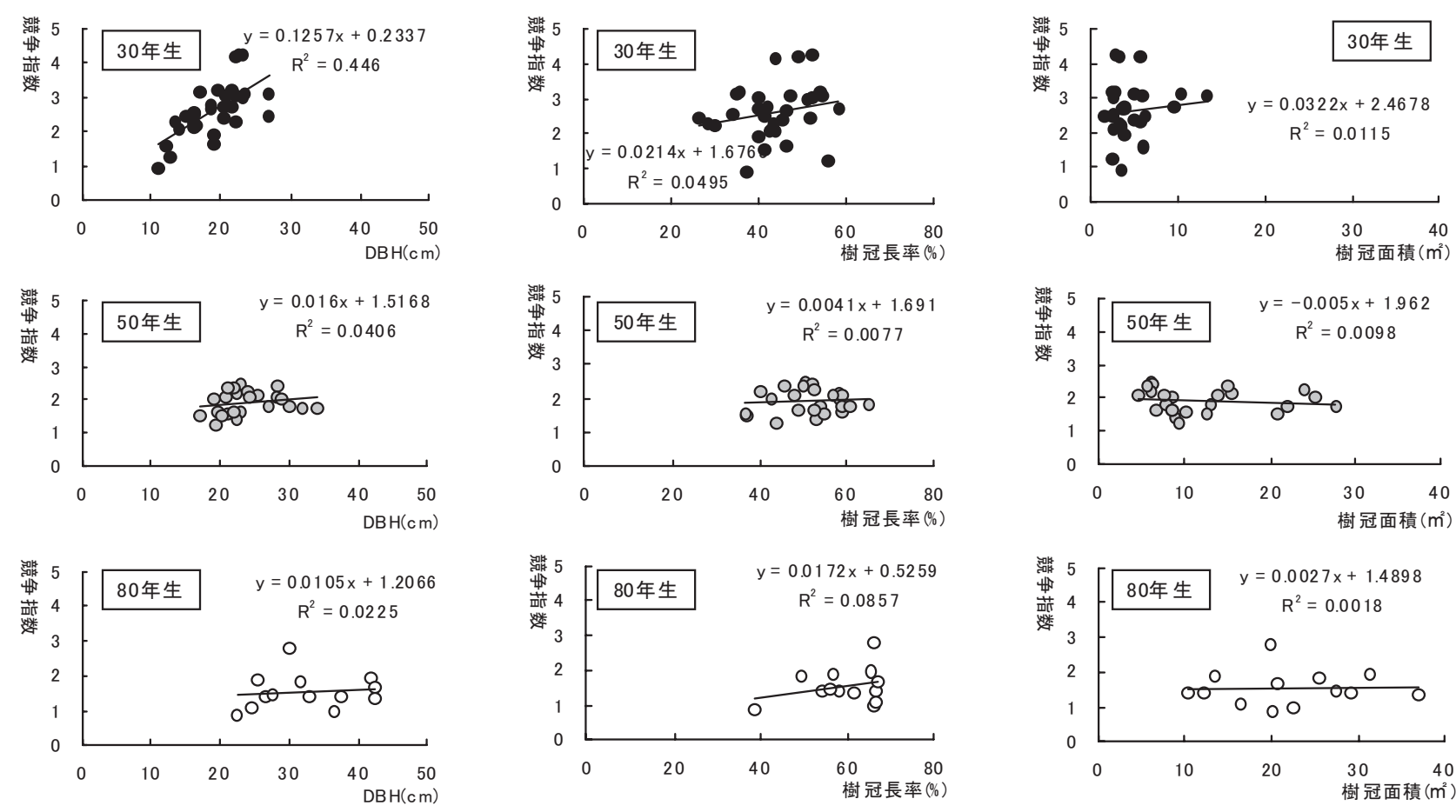

競争指数之 $\mathrm{DBH}$ の関係 （上から 30 年生, 50 年生, 80 年生)

競争指数之樹冠長率の関係

(上加ら 30 年生, 50 年生, 80 年生)

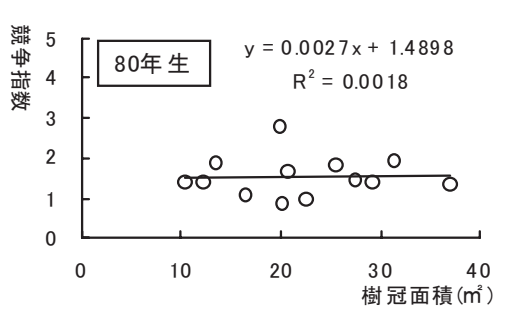

競争指数之樹冠面積の関係 （上から 30 年生, 50 年生, 80 年生)

\section{図－6＼cjkstart各プロットの競争指数と樹形因子との関係}

を規定するどの因子とも相関関係がないこと（ $\mathrm{r}^{2}=0.18$ 以下） が示された。さらに 30 年生では DBH で低い相関を示したに過 ぎず $\left(r^{2}=0.45\right)$, その他の因子については競争関係は樹形を規 定するどの因子とも相関関係がないこと（ $r^{2}=0.12$ 以下）が明 らかになった。

\section{6. 考察}

通常, 生活環境保安林や森林公園での森林整備における間伐時 期の指標は施業林と同様に設定し, 林齢に対応する成立本数や相 対幹距比, 形状比などを目安とする。このような視点で検討した 場合, 3 プロットとも以上の全ての点において, 特に 80 年生の プロットに扔いては樹高因子から鑑みて林木にとっての土地生産 力が限界に達しつつある点からあ, 要間伐林とみなされた。

一方, 全てのプロットで形状比はそれほど高くなく, 通常冠雪害 などに対して危険といわれている90〜100には達していない。さ らに樹冠長率も拈よそ $50 \%$ 前後で比較的高く, 一般的にイメ一 ジする線香林とは異なる様相がうかがえた。

立木配置に関しては分散構造より, 30 年生ではランダム分布,
50年生では一様分布に近いランダム分布を呈した。これはスギ・ ヒノキ人工林に対して行われた既存の報告とほぼ類似した結果で あり ${ }^{14)}$, 調査地が人工造林地であることから当然の結果といえた。 一方, 80 年では集中分布が見られたが，聞き取り調査により過 去にサイズの大きな個体を抜き切りしたことによって林冠ギャッ プが生じ, 同時に残存木によっていくつかのサイズの異なる集中 分布を呈したと考えられた。これらの立木配置は，樹冠の大きさ のばらつきにも影響し, 林冠の疎開部とうっ閉部での樹冠面積の ばらつきがほかの二つのプロットと比較して大きくなったと考え られた。

$\mathrm{DBH}$ と樹高の関係では, 80 年生は DBH と樹高の相関が低かっ た。これは平均值付近に樹高が集中したことに起因した。樹高因 子は土地の生産力に影響されることは良く知られているが5 $)$, 地 位に対してもこのプロットの平均值が上限值に近い樹高であった ことから，このプロットでは林木はすでにこの土地の生産力に成 立しうる上限近くまで達しつつあることが示された。また， DBH の值にはばらつきが見られたが，これは前出の林木配置か ら，林木の相対的な分布のばらつきに即応して DBH の大きさに 
ばらつきを生じたと考えられた。これに対して 30 年生, 50 年生 に関しては DBH と樹高の相関が 80 年生と比較して高く, DBH と樹高共にばらつきも大きい。樹高因子, という視点で検討した 場合, 両プロットでは 80 年生と比較して地位と林齢に対する樹 高曲線の上限值に対してまだ余裕があり, 土地生産力にいまだ余 力があると考えられた。DBH の結果と共に鑑みれば，両プロッ 卜では土地生産力の上限に向かい, 個々の林木の個体サイズ等に 即応した生長をしている状態であると考えられた。

このように林齢, 成立本数, 立木配置やそれに伴う成長の状態 の異なる 3 つのプロットでの競争指数之, 各樹型, 樹冠形成因子 の間には相関関係はいずれも無く, わずかに 30 年生の競争指数 と DBH の関係で見られたのみであった。樹冠形の变化は, 対象 木の枝が隣接木之の枝同士の光獲得競争に敗れ, 枝の生産量の収 支が減じる，むしくはマイナスになることによってシュートの伸 びが停滞し, 枝が落ちる事によって生じるといわれている9 。こ の関係は枝単位からやがて, 林木の個体単位で被圧する側とされ る側という関係が成立する。この点で, 林木相互の競争状態が $\mathrm{DBH}$ と相関のない 50 年生と 80 年生は, 同化器官である葉が隣 接木との競争の影響を受けていない事を表していると考えられた。 30 年生に関しては低いながらも相関関係が見られることから, 隣接木との競争状態は弱いながらあ生じ始めていると考えられた が, 競争は樹冠形, 換言すれば枝同士の競争関係として未だ顕在 化していなかった。以上のことは，すべてのプロットにおける形 状比の低さや樹冠長率の高さなどからも考え得る結果であった。 ヒノキが他の樹種と比較して耐陰性が強く, 照度のかなりの低下 にも生存できることによって, 競争が個体内で相対的に激しいと 思われる下部の枝でさえも低い呼吸量であ生命を維持できること から, 被圧され始めてから落枝までに至る時間が長いことがこの ような結果を生じさせた要因だと考えられた。

以上より，通常の施業林の指針に照らし合わせた場合，高密な プロットであるため, 要間伐林として位置付けられた全てのプロッ 卜は, ヒノキの生態的な状態として検討した場合, 現段階の成立 本数ではヒノキにとって高密とはいえず, 高密な状態故に上層木 の健全性が損なわれているということは結果として導き出せなかっ た。このような結果のくい違いは，ヒノキ人工林の施業指針が歴 史的に吉野杉林業の施業体系を踏襲したものであって, 間伐など の施業指針が生態的な視点よりも林業経営的な視点から体系立て られたことに起因すると推察された2)。

樹冠開空度と相対幹距比との関係は, 30 年生では他の二つの プロットと比較して相対幹距比が低く, 樹幹開空度もそれに伴っ て低かった。一方, 50 年生と 80 年生での相対幹距比は 17.05 と 19.95 で, 值の違いがあったのにもかかわらず, 樹冠開空度の平 均值は近かった。これは 80 年生の值には 50 年生には見られない ばらつきがみられ, 立木の平面配置の違いによって生じたうっ閉 部と疎開部での值のばらつきによる結果であると推察された。そ れぞれのプロット間で樹冠開空度に相違はあるあのの, すべての プロットで 20\%以下であり，かなり低い值と考えられた。

ヒノキの放置人工林の大きな問題点のひとつに, 林冠の過度の うっ閉のため, 林内照度が減少し, 林床植生の消失が挙げられる。

このことは林地の次代の主木となる林木の育成, すなわち森林 の恒続性の確保を困難なものにし，さらにうっ閉期間が延長され た場合, 林床の裸地化を促し, 土㙵の侵食など林地の健全性に重

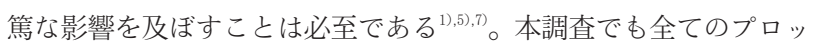
トの林床部の植生は貧困であり, これは長い期間の放置による上 層木のうっ閉によるものだと考えられた。30 年生では樹冠開空 度は低く林床全体が樹冠によりうっ閉され, 林床植生の被度は他 の二つのプロットと比較して低かった。特に次代に高木層を構成 すると期待される亜高木層での個体数は数本にとどまり, さらに

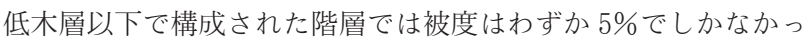
た。

また, 50 年生, 80 年生は 30 年生と比較して林床の被度は高く, 亜高木層も存在していたが, 構成種は中低木類の個体によって占 められ，次代の高木類の個体数は少なかった。さらに樹冠開空度 はいずれも低く, 今後の放置によって林床はさらに衰退すること が考えられたことから，林床植生に関してはいずれのプロットに おいてもこれ以上の放置は林地の健全性と森林の恒続という観点 から重篤な弊害をむたらすことが示された。

全プロットにおいて, 慣例的に間伐遅れとみなされた林分であっ たが，上層木についてはヒノキという樹種にとっては競争関係の 激化，また関係そのものが確認できず，現段階では 50 年生, 80 年生では樹形や樹冠形の違いは個々の林木の自己サイズに依存し たものであることが示された。30 年生についてはヒノキの樹種 特性により, 競争は樹形に反映しない程度であったことが示され, 相当高密である本調查対象地に抢いてさえ, 樹型級の判定を用い た選木方法は困難である事が明らかになった。一方, 林床に関し てはその健全性や次代の主木の確保という観点から, 強度の間伐 による下層植生誘導が急がれる事が考察された。以上より，一般 的に高密むしくは超高密で間伐遅れといわれるヒノキ林に関し， 上層木の育成よりも下層植生の誘導を優先するべきであるという ことが考察された。

前報で筆者らは「風致間伐」によって断続的に創出された林冠 ギャップによって，同じ本数の通常間伐よりも下層植生導入が効 率的であって, 森林の恒続という点においても将来の見通しが相 対的に明るいということを報告した。これらの調査結果より, ヒ ノキ人工林においては「風致間伐」の定義を損なわず，複雑な樹 型級に頼らない別の容易な選木方法にて適切な林冠ギャップを作 り出す必要があると考えられた。

本報で得られた結果から，七ノキ林の当面の問題として上層木 の保育よりも, 早期の下層植生導入が必須である。これは林地の 中でも選木しやすい存在である優勢木, つまりサイズの大きな林 木を伐採することで少ない伐採本数で効率的に，断続的な小ギャッ プが開けることによって達成できると考えられた。これに加えて, 大きな個体から伐採することは上層間伐であり，これは主伐以前 の中間段階での収益を見込めることによって,森林の風致と木材 収穫を一元的に行える針広混交の択伐林型を目指す，ヒノキ人工 林林相転換の第一段階の「風致間伐」と考察された。

\section{謝辞}

本研究を遂行するにあたって, CAD ソフト内部言語にてプロ グラミングをして下さった, 長野県上伊那地方事務所林務課森林 路網係の斎五澤貴史氏には多大なるご助力をいただきました。ま た，飯島町役場産業振興課の皆様には調查地を探していただきま した。さらには同町共有林の代表者の方々にも調查を快諾してい ただきました。また, 信州大学農学部造園学研究室の横矢美和氏, 鈴木尚氏, 米田裕征氏, さらに同大学緑地生態学研究室の水野敦 氏, 木材利用学研究室の碓井伸幸氏, システム環境コンサルタン 卜株式会社の佐々木通子氏には酷暑の中, 調査を手伝っていただ きました。皆様にはこの場を借りして厚く御礼を申し上げます。

\section{補注及び引用文献}

1) 赤井龍男（1998）：低コストな合自然的林業：全国林業改良 普及協会, $143 \mathrm{pp}$

2 ）飯田繁（1975）：造林一その歴史と現状一：日本林業調査会, $129 \mathrm{pp}$

3 ）伊藤精晤・馬場多久男（1989）：人工林の風致間伐のための 残存木と伐採木の選定に関する考察 : 造園雑誌 52, 199-204 
4 ）大永貴規（1986）：森林のレクリエーション利用の新しい展 開に向けて：森林組合 198, 8-12

5 ）川名明・片岡寛純・角張嘉孝ほか（1992）：造林学：朝倉書 店, $200 \mathrm{pp}$

6 ）小林四郎（1999）：生物群集の多变量解析：青樹書房：2637

7 ) 四手井綱英・赤井龍男・斉藤秀樹・河原輝彦（1974）：ヒノ キ林一その生態と天然更新 - : 地球社, $375 \mathrm{pp}$

8 ）清水裕子・川崎圭造 - 伊藤精晤（2003）：人工林の風致間伐 による林相変換の可能性 : ランドスケープ研究 66(5), 517520

9 ) 竹中明夫（1997）：植物は形で勝負する一光資源獲得のため の「形」-：科学 67(8), 616-623

10）寺崎渡（1928）：間伐法要綱：大日本山林会，239pp

11）原田文夫（1983）：信州のからまつ：107～133：リンケイ新 聞出版局

12) HEGYI, F. (1974) : A simulation model for managing jack-pine standssimulation: RoyalColl. For, Res. Notes30, stockholm, 74-90

13）本田静六（1968）：森林家必携：林野弘済会, 731pp

14）宮本麻子・天野正博（2002）：立木の空間分布抢よび生育条

15）山下隆之祐（1986）：森林レクリエーションと森林組合：森 林組合 198，5-8

16）早稲田収（1983）：人工林の複層林施業に関する研究（I） 光環境の測定方法－開空度の測定とその光環境示標としての 応用一：林業試験場研究報告 $323,9-13$

17）風致間伐の伐採木の選定基準は, 風致的見地に立って保残す る主立木を決め, その主立木に対する競争関係から（位置関 係や，サイズの大きさ，樹形等から）隣接木・周辺木を，当 分の間主立木の成長に支障をきたす心配のない立木を主立木 に従った木として従立木とし, 次世代の主立木として期待さ れる木を次主立木, 将来的に種内, 種間競争に破れての枯死 を予測して今は残して置く木を暫立木と位置づけ，それ以外 の立木を伐採木として選定した。主立木を第一級木，次主立
木，暫立木を第三級木，従立木を第二級木に置き換えた場合， 主立木が風致的な視点によって選木される事以外は寺崎式樹 形級区分と類似している。

18）樹冠長とは樹冠の垂直的な長さであり，樹高から枝下高を差 し引いたものを言う。また，樹冠長率とは樹高に対する鉛直 方向の樹冠長の割合（(樹高一枝下帯）・樹高・100）である。

19）本研究では分布様式の判定法として下記の式を用いて Morishita のI $\delta$ 指数で判定した ${ }^{10)}$ 。

$$
\begin{gathered}
\delta=\mathrm{q} \sum_{\mathrm{i}=1}^{\mathrm{q}} \mathrm{ni}(\mathrm{ni}-1) / \mathrm{N}(\mathrm{N}-1) \quad \mathrm{I} \delta=\mathrm{q} \delta \\
\mathrm{N}=\text { 総個体数 } \mathrm{q}=\text { 方形区の数 } \\
\mathrm{ni}=\mathrm{I} \text { 番目の方形区内の個体数 }
\end{gathered}
$$

$\mathrm{I}_{\delta}$ の值はランダム分布の時は 1 ，集中分布の時は $1>\mathrm{I} \delta$ とな り，一様分布のときは $1<\mathrm{I} \delta$ となる。

20）本論での「風致間伐」は伊藤 $\left.{ }^{3}\right)$ が行ったものを指す。この 間伐方法は，間伐後の残存木の径級分布はザリッシュ（V. Salish）のポステル間伐法に類似し，林木配置は群状保残の 形態をとる。この方法によって，森林を択伐林型へ導く事を 目標とし，これはメーラーの恒続林思想の森林美と経済の一 元化を目指すとされている。

21）相対幹距比之は, 林木の平均樹幹距離 (平均幹距) と林分の上 層木の平均樹高との比であり，林分密度の尺度として用いら れ，略語として $\mathrm{Sr}$ が使用される。相対幹距比は以下の計算 によって求められる。

$$
\mathrm{Sr}=\left\{(\mathrm{F} / \mathrm{N})^{1 / 2} / \mathrm{H}\right\} \times 100
$$

$\mathrm{F}$ : 単位面積 $\left(\mathrm{m}^{2}\right), \mathrm{N}$ : 単位面積あたりの本数 (本), $\mathrm{H}$ : 樹高 $(\mathrm{m})$

以上の式によって求められた值にはランク付けされる。 Sr19〜22 で低密，17〜19 で高密，16〜17までは過密，16 以下は超過密となり，值が低いほど過密であるといえる。

22）本来ならば対象木を中心とする半径 3. $05 \mathrm{~m}$ 以内の樹木を競 争木として算出するが，本論では対象木に樹冠が隣接する距 離の近い順から 5 本抽出し, 計算した。また, 林縁木, ヒノ キ以外の樹木は除外した。 